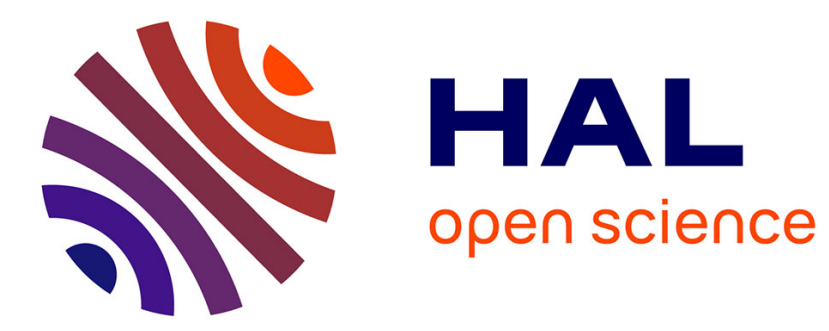

\title{
Between the Cloister and the World: The Successful Compromise of the Ursulines of Toulouse, 1604-1616 \\ Laurence Lux-Sterritt
}

\section{To cite this version:}

Laurence Lux-Sterritt. Between the Cloister and the World: The Successful Compromise of the Ursulines of Toulouse, 1604-1616. French History, 2002, 16 (3), pp. 247-268. hal-01060157

\section{HAL Id: hal-01060157 https://hal.science/hal-01060157}

Submitted on 3 Sep 2014

HAL is a multi-disciplinary open access archive for the deposit and dissemination of scientific research documents, whether they are published or not. The documents may come from teaching and research institutions in France or abroad, or from public or private research centers.
L'archive ouverte pluridisciplinaire HAL, est destinée au dépôt et à la diffusion de documents scientifiques de niveau recherche, publiés ou non, émanant des établissements d'enseignement et de recherche français ou étrangers, des laboratoires publics ou privés. 
Between the cloister and the world: the successful compromise of the Ursulines of Toulouse, 1604-1616.

\section{By Laurence Lux-Sterritt*}

The seventeenth century signalled a new era for French Catholicism; after the troubled years of the Wars of Religion (1562-1598), and the religious toleration granted to Protestants in the Edict of Nantes, the Catholic devotional revival known as the dévôt movement quickly gathered momentum across the realm. ${ }^{1}$ The dévôt religious outlook promoted a deeper trend of piety, a life in imitation of Christ, and an apostolic message that aimed to tighten the links between the Church and its flock. ${ }^{2}$ Confronting the success of Protestant schools addressing both female and male audiences, the Catholic mission gave particular emphasis to its educational impulse and multiplied its efforts to catechize the multitude and strengthen the bases of the Catholic faith among the laity.

One of the distinctive features of this seventeenth-century Catholic revival was what Elizabeth Rapley called 'the feminization of the Church', a phenomenon that manifested itself both in the renewed appeal of traditional monastic life and in the multiplication of new companies of filles séculières and of teaching congregations. ${ }^{3}$ By the middle of the seventeenth century, there were more nuns than monks and friars in France and, in parallel, the proportions of women in mixed lay confraternities sometimes increased to more than 80 per cent. ${ }^{4}$ Characteristically, female lay involvement in the French Catholic Reformation was even more ardent than its male counterpart. ${ }^{5}$ French dévôtes rediscovered the practice of charity and dedicated their time to good works, following the example of the renowned Mme Acarie (15661618), who was linked with the first Ursuline establishment in the faubourg SaintJacques in Paris. ${ }^{6}$ This wave of female religious exaltation naturally led to the formation of numerous lay congregations that specialized in works believed to be 
particularly suited to women, such as relieving the poor, attending to the sick or educating girls. The intensity of such lay activism was characteristic of the seventeenth-century Catholic reformation.

In the movement geared towards the religious education of the masses, female congregations had found a niche that channelled their contribution to the Church's apostolate. In the city of Lyon alone, nine schools were dedicated to boys' education, but ten were dedicated to girls' ${ }^{7}$ Against the general early-modern background of feminine submission, the first decades of the seventeenth century offered an oasis of possibilities where women's opportunities reached far beyond their traditional roles both within the Church and in society at large. Women's communities became involved not only in the devotional life of the Church, but also in its active life with the multiplication of apostolic vocations to re-Catholicize their country. ${ }^{8}$

The city of Toulouse, which will be the focus of this study, mirrored this national phenomenon precisely. After the Wars of Religion, the municipality of Toulouse remained resolutely Catholic, but the influential ville parlementaire was a city under siege, surrounded on all sides by areas of Calvinist conviction in the Languedoc and Guyenne. ${ }^{9}$ Studies of its municipal registers indicate that, hard-line commitment apart, a considerable proportion of the city's key middle class had become undecided, confused, or even uninterested in religious practice. ${ }^{10}$ Thus, the area's extensive Protestantization offered a wealth of opportunities for religious initiatives, whilst presenting equally numerous challenges. ${ }^{11}$ Local historian Bennassar wrote: 'In the Wars of Religion, the Toulousain way became clear. The city would be the Catholic stronghold in a region of which three-quarters were held by Protestants. It would, therefore, be the theatre of the most violent Catholic reaction. ${ }^{12}$ Influenced by the post-Tridentine impulse given by Carlo Borromeo, (archbishop of Milan 1566-1584), the Cardinal-Archbishop of Toulouse (1588-1605), François de Joyeuse, would be the architect of the city's vigorous Catholic counterattack. $^{13}$ 
The efforts of Cardinal-Archbishop Joyeuse were quickly rewarded by a remarkable devotional movement which involved unprecedented proportions of women. ${ }^{14}$ In Toulouse, existing convents opened their doors to increasing numbers of entrants each year, while lay congregations flourished. The Congregation of Saint Catherine of Sienna, for instance, undertook apostolic relief for the poor; the Madeleines repenties cared for 'fallen women', the Dames du Saint-Sacrement cared for the sick, and the Dames de la Miséricorde specialized in visiting prisoners. ${ }^{15}$

It is universally acknowledged that the French feminine educational drive was spearheaded by the Ursulines, which Rapley has called 'the feminine teaching congregation par excellence'. ${ }^{16}$ By the end of the century, there were an estimated 320 communities across the realm of France, all combining a convent and a school for day pupils. ${ }^{17}$ However, it has often been erroneously assumed that the congregation of Paris was the leader of the distinctive French Ursuline experiment. This accolade, in fact, belongs to the establishment of Toulouse which, in 1604, was the first house to stem out of the original settlements in Provence and the Comtat-Venaissin and adopt a form that was less directly in keeping with their Italian roots.

The history of the Ursulines epitomizes a growing female desire to take an active part in the Catholic Reformation. In 1535 in Brescia, Angela Merici (14741540) founded gathering of lay women, which she called the Ursulines. ${ }^{18}$ They lived separately in their own homes, undertaking apostolic and educational works with girls and women. Although it was as an informal lay movement that they gained Pope Paul III's approval in 1544, the archbishop of Milan, Carlo Borromeo, soon organized them into communities under the authority of local bishops, thereby creating the first Ursuline congregations. This formula, half way between the religious and the secular, reached Provence and the Comtat-Venaissin in the late sixteenth century and provided the model for the congregation of Avignon, led by Françoise de Bermond (15721628) and her director César de Bus (1544-1607), founder of the Fathers of the Christian Doctrine. Pope Clement VIII (1523-43) granted the Ursulines permission to teach the Christian doctrine to the girls and, on occasion, to the women of Avignon. 
Their endeavours were crowned with such success that new houses opened quickly in towns such as Chabeuil, Aix-en-Provence, Arles and Marseille. ${ }^{19}$

The year 1604 marked the first settlement of a new Ursuline congregation outside Provence and the Comtat-Venaissin; one of the conseillers au Parlement de Toulouse, Arnaud Bourret, became aware that the Ursulines (and their male counterparts, the Fathers of the Christian Doctrine) would be a valuable asset in the Catholic drive that was sweeping the city. He understood that the Avignon formula of congrégées, unfettered by conventual enclosure, would be ideally suited to reach out to the broad range of the local female population. Thus, Bourret appealed personally to César de Bus, requesting two Fathers of the Congregation of the Christian Doctrine to run a school for boys and two Ursulines to manage a school for girls. $^{20}$ Cardinal-Archbishop François de Joyeuse, eager to further the city's mission of education and evangelization, seconded Bourret's letter with a request of his own, asking for the establishment of the two communities specifically to teach Christian doctrine. ${ }^{21}$ César de Bus responded to Joyeuse's request and, on 14 October 1604, Marguerite de Vigier (1575-1639) and Françoise de Blanchet (no dates available), accompanied by two Fathers of the Congregation of the Christian Doctrine (Antoine de Vigier, Marguerite's brother, and Pierre Sisoine) arrived in Toulouse to establish new branches of their respective congregations. ${ }^{22}$ Thus, the community of Toulouse was the first to stem out of the early settlements in Provence and the ComtatVenaissin.

\section{I}

The Ursuline archive in Toulouse provides a vivid illustration of the tactics used by the sisters to create the new, pioneering model of the teaching nun that was to have such impact on the female educational and religious landscape of seventeenth-century France. $^{23}$ The documents show how this practically-minded congregation (correct trans?) developed a formula that enabled it to serve the Church's active educational mission in the world without, however, breaching the conservative decrees of Trent 
which, in 1563, had endorsed Pope Boniface VIII's Bull Periculoso (1299) and enforced strict enclosure upon all female religious Orders. ${ }^{24}$

Initially, Vigier and Blanchet benefited from the kindness of conseiller Bourret, who personally provided them with lodgings in his own home before eventually purchasing a house for them in the Rue des Trois Rois Vieux. ${ }^{25}$ There, the first congrégées began their works of education with the city's local girls. They immediately took on boarders from families who could afford the pension but, crucially, they also ran open day-classes for externs in conjunction. Indeed, the motivating force behind the Toulousain Ursuline experiment was the congrégées' desire to take part in the drive that was transforming this once-disputed city into the leader of French provincial Catholic reform. Schooling, therefore, was vested with primary importance, since it provided the forum for the evangelization of girls. Parayre, in his Chronique des religieuses augustines ursulines de la congrégation de Toulouse highlighted the fact that the Ursulines were a teaching and evangelizing congregation, as opposed to a purely contemplative order, and underlined their apostolic and educational brief as the essential core of their vocation. He wrote: ' [the Ursulines] relate contemplation to the instruction of souls, which is their principal aim, in order to teach girls the mysteries of Christian religion and the practice of virtue'. ${ }^{26}$ The community's book of Constitutions confirms the teaching of Christian doctrine as the primary vocation of the house founded by Marguerite de Vigier and Françoise Blanchet. ${ }^{27}$ The section on the vocation opens unequivocally: 'The principal aim of this institute is to instruct girls in Christian doctrine and in good morals $[\ldots]$ according to the study that is proper and suitable to their sex. ${ }^{, 28}$

Of course, the crux of the instruction provided by the Toulouse community was confessionalization rather than academic education per se. The manuscript book entitled Constitutions of the school and monastery of the convent of Saint Ursula of Toulouse provides an interesting insight into the way in which the house valued secular teaching compared with religious instruction. It states: 
[The Ursulines of Toulouse] will teach the aforementioned girls in the Christian doctrine, in piety and in the practice of [Christian] virtues; in order to do this, they will teach them to read, write and sew to the best of their abilities. ${ }^{29}$

For Vigier's Ursulines, schooling in the elementary skills of reading and writing was necessary in order to enable their pupils to become more closely acquainted with the catechism and Catholic doctrine. ${ }^{30}$ Thus, secular teaching was essential to Ursuline commitment, but mainly insofar as it provided teachers with opportunities to catechize youth. ${ }^{31}$ In his seminal work on the early communities of Provence and the Comtat-Venaissin, which were heavily influenced by their Italian exemplars, Ursuline historian C. A. Sarre found evidence that the primary mission of these houses was to catechize rather than to educate. Similarly, the manuscripts of the early congregation of Toulouse also highlight the teaching of Christian doctrine as the core of its mission. ${ }^{32}$ This seems to have been the case across France in general, and has been noticed for the communities of Paris, Bordeaux and Burgundy. ${ }^{33}$

Moreover, the essence of the congrégées' vocation was to stamp the basics of Catholic doctrine even in the minds of those who could not enter the traditional classrooms of the city's boarding establishments. Thus, unlike traditional convents, the Ursulines of Toulouse did not primarily aim to train future novices in religion. Rather, they launched their school to secure and strengthen the faith in girls who, in time, would marry and have families of their own. ${ }^{34}$ Their special participation in the Toulousain Catholic revival was their Christian training of wives and mothers for future generations. By teaching externs, the house at Toulouse aimed to address the whole spectrum of the city's female population, without restrictions of social background. Thus, in its devotion to its catechetical vocation, the small Ursuline community fitted perfectly into its local context. Its music played its part in the overall symphony of the Toulousain Catholic renaissance; even more essentially, it completed its tune by providing its own particular note: its educational and catechizing vocation for local girls. As the sisters' house experienced increasing 
success, it became known for the excellence of its school and the dedication of its teachers.

The example of one of the initial members of the community, Marie de Liberos (born 1574, in religion soeur de la Trinité), illustrates this point eloquently. ${ }^{35}$ Significantly, she claimed to see a lighted torch (a traditional emblem of pedagogy) burning by her side as she was teaching her classes. Liberos believed this torch represented her community's educational endeavours and the excellence of its Christian aim. Her predilection for teaching was such a precious asset for the community that she was among the few select sisters who later left Toulouse in order to help newer houses in rural areas. ${ }^{36}$

Nor was Liberos an isolated case in the community. Her consoeur Catherine de Pins de Montbrun (1585-1664, in religion soeur de Saint Bonaventure), was equally dedicated to her teaching brief. ${ }^{37}$ According to Parayre, she refused to take her thirty-minute break each day, but insisted on employing it to teach and help girls individually. As with Marie de Liberos, her efficiency in the classroom was used to optimize Ursuline success in the region and she was later sent to found a new community in nearby Auch. Another congrégée, Jaquete de Maynie (1588-1632, in religion soeur de Saint-Jean l'Evangéliste) displayed the same concern for her Ursuline educational and evangelizing vocation. ${ }^{38}$ A daughter of one of the most noble and powerful families in the city, she had herself been tempted by the distractions of the wealthy society in which she lived. Parayre's account described her as an idle young girl, full of social ambitions and delusions of grandeur. He wrote: '[her] Christian practices were not only dissipated by it but altogether infected and corrupt'. He recounted the episode of her conversion as a miracle, saving her from the perils of what he referred to as dangerous 'books of fashion and profane stories'. In the chronicler's words, 'these thoughts possessed her so absolutely that they were strong enough not only to distract her in her prayers and in all devotional practices, but also to make her abandon them altogether. ${ }^{39}$ Perhaps as a consequence of her own conversion, Jaquete de Maynie became one of the most active catechizers 
of the initial congregation. Her awareness of the Ursuline vocation as one that was essentially educational led her to play a crucial role in ensuring that the community remained devoted to this brief even after the major structural changes that were to occur as the congregation was elevated into a convent between 1614 and 1616 . To her, it was crucial that, in embracing conventual life, the community did not become entirely devoted to the contemplative life of Mary, but continued undertaking the duties of Martha as well.

The early Ursulines in Toulouse seemed deeply attached to their dual essence, and were proud to combine the duties of Martha with the spirit of Mary. A manuscript book kept by the congregation and entitled Memoirs of the beginning and progress of the Order of Saint Ursula covers the years between 1604 and 1621. Its opening statements define the nature of the establishment eloquently:

The life of Ursulines is none other than that which the Son of God, his Holy Mother and the apostles led in this world [...]. Such are the exemplary models followed by their status and their profession: it is the mixed life, embracing both contemplation and action... ${ }^{40}$

Indeed, for the first ten years in Toulouse, the Ursulines were not nuns but only congrégées. ${ }^{41}$ The canonical distinction was crucial, for the members of a congregation - as opposed to those of an order - were bound only by simple, private vows and not solemn ones: thus, their legal status remained that of lay women, not nuns. The congrégées did not obey any monastic rule nor observe enclosure, and were relatively free from ecclesiastical control. They represented a sort of halfway house between the lay and the religious world. 
As they busied themselves in the evangelization of local women and girls, the Ursulines seemed to show no signs of preoccupation about their status or their designation. The house operated as a community of lay women under private vows: thus, the establishment corresponded to no recognizable category. It was more than a simple lay sorority, since the congrégées lived in a community with its own hierarchy and regulations; yet, they were emphatically not nuns, since they took no solemn vows and did not observe strict enclosure. Between 1604 and 1609, documents show no evidence of any consideration for constitutional arrangements that would define its status and correct this anomalous position. Thus far, these technicalities remained secondary to the practical pursuit of the congregation's catechizing vocation. Indeed, at that juncture, the establishment in the rue des Trois Rois Vieux was more preoccupied with carving a niche for its educational vocation amongst local women than with the pursuit of ecclesiastical recognition. Yet, despite working assiduously for the Church, the congrégées were in breach of Church decrees. Such contradictions would need to be resolved if the Ursulines were to secure official acceptance for the work they insisted on carrying out, and the difficulties encountered by the early Toulousain congrégées provide an eloquent example of the preoccupations of their contemporaries with status classification and order.

In her authoritative study of the Ursuline Order in France, M. C. Gueudré stated that most municipalities showed no inclination to regularize the administrative situation of new Ursuline houses; on the contrary, the congrégées often experienced difficulties in gaining approbation from their local authorities. ${ }^{42}$ This was the case in Toulouse, where the local Parlement, although an essentially Catholic body actively involved in the city's Catholic renaissance, had refused to recognize the community officially before it was approved by the king. ${ }^{43}$ However, it was only in 1611, as a result of conseiller Bourret's efforts, that the community of Toulouse finally secured royal lettres patentes; in them, Louis XIII gave, for the first time, his approbation to 
an Ursuline establishment in France, entrusting it 'to promote by all necessary means the service of God and the salvation of souls'. ${ }^{44}$ Although the community was in breach of Tridentine definitions, Louis XIII praised it as an establishment of 'great profit and edification'. ${ }^{45}$

Once the congregation was eventually recognized by the king, the Parlement showed no trace of hesitation in receiving it wholeheartedly, although it was not as yet approved by the pope. Thus, the community became officially registered by the Parlement of Toulouse in April 1612, eight years after its settlement in the city in 1604, but only a few months after securing Louis XIII's assent. The motivations behind the Parlement's refusal to recognize the early congregation remain unclear; was it wary of a congregation of Italian origin, therefore considering royal approval as a pre-requisite for its own endorsement of the Ursulines? Or did its reservations spring from more pragmatic concerns?

The community's foundress, Marguerite de Vigier, was only too aware both of the general public's suspicion of novelty and of the fragility of the reputation of female enterprises. During her initial journey from Avignon to Toulouse in 1604, her little troupe had even been arrested on suspicion that they were 'gens de mauvaise vie. ${ }^{46}$ This anecdote illustrates vividly how seventeenth-century perceptions frowned upon geographical mobility in general, and upon that of unmarried women in particular. Early-modern conceptions understood women as confined either within the sphere of their household or that of a convent. This, of course, was not specific to the Toulouse experiment: across Europe, female initiatives (whether social, economic, political or religious) faced both the underlying misogyny of the male ruling classes in Church and state and the profoundly patriarchal nature of early modern society. Catholic clerics and laity often received the women who were dedicated to the revival of the faith with a strong blend of suspicion and mistrust. Thus, gender-defined stereotypes exercized considerable influence even upon missionary movements that ultimately transformed the practical sphere of women from one of humble subjection to one of relative initiative. Linda Lierheimer has noted that such restrictions affected 
the Ursuline movement all across France since, as she puts it, 'their ambiguous status and their incursions into public spaces were disturbing' to early-modern society. ${ }^{47}$ It therefore comes as no surprise that the Toulouse settlement needed to prove its good credentials before it gained the support of the families of the local elite.

Parayre's Chronique illustrated the difficulties that brought the early community, with its unenclosed lay status and its free open school for all, into direct conflict with some of these influential families. One incident concerned Magdelaine Despanez (1594-1677), in religion soeur de Jésus, whose father, a trésorier général de France, had promised her for an advantageous marriage in 1606. However, the young girl, who was not yet twelve years old, broke all the arrangements when she escaped and found refuge with the Ursulines. ${ }^{48}$ One can understand her family's discontent at the loss of potential income and status, which was in this case further aggravated by the blatant disobedience of their child. Moreover, their daughter had found a haven in a small and unapproved congregation of women which was, as yet, far from enjoying the distinction, prestige and, above all, the good reputation of some of the city's established convents. Yet, the girl's parents were of a devout disposition; eventually, they complied with their daughter's choice without attacking the community as virulently as might have been expected. In this case, a well-to-do family relinquished personal interest and social alliances to oblige their daughter's desire to stay with the Ursulines and become a simple congrégée.

Things did not go so well, however, for the young Marie de Liberos. Like Despanez, she also fled a pre-arranged union by finding refuge with the Ursulines. ${ }^{49}$ However, in her case, parental consent was not so easily gained as for her consoeur. Originally from the smaller town of Agen, she had been sent to Toulouse under her uncle's tutelage, in order to meet her future husband and finalize the settlement. When she ran away to the safety of the Ursuline house, both uncle and suitor attempted to break down the house's doors and kidnap her. An embarrassingly public battle of wills followed; when the use of force was finally abandoned, it was substituted with court action on the part of the enraged uncle, who sued the Ursulines 
for holding his niece illegally. The community eventually won after a long legal battle, and Marie de Liberos was soon sent to a new branch of the community, in the nearby town of Brive-la-Gaillarde.

The vulnerability of the community's reputation and the unconventional nature of its status can be illustrated further with one last vignette. Françoise Rabonite (d. 1654), in religion soeur de Sainte-Claire, was the daughter of an avocat en la cour du Parlement; she was destined to follow in the footsteps of her sisters, who were nuns in the city's prestigious convent of Saint Claire. ${ }^{50}$ However, despite having been educated as one of its boarders, she refused to enter the novitiate there. ${ }^{51}$ Instead, she preferred the poverty of the Ursuline congrégées, whose apostolic vocation had already won her heart, and whom she stealthily joined in 1607 . On discovering her initiative, Parayre recorded, her mother was deeply upset. One of her uncles, a procureur au Parlement, even tried to get her out by force. Significantly, respectable neighbouring families united to support Madame Rabonite in her plight, and stood at the Ursulines' doors demanding Françoise's release and shouting abuse at the community. Indeed, although most Catholic families approved of the congrégées' religious cause, their institutional status implied that the house's financial stability remained uncertain. Thus, most fathers of influential households preferred safer placements for their daughters, in convents whose prestige was proven and longestablished. When her mother faced her with an ultimatum, Françoise Rabonite chose never to see her family again, and decided to remain with the Ursulines. The community's Memoirs relate the incident:

Françoise Rabonite [...] presented herself to the community with such fervour and such generosity that she resolved, for the love of God, never to see her mother again, the later having opposed and resisted [her daughter's] decision as much as she could, and declared that she would never see her again in her life ... 52 
Thus, Françoise Rabonite's choice ran against early-modern conceptions when she refused the grandeur and kudos of the Saint Claire convent and favoured the small, fragile and unrecognized Ursuline community, much to her parents' distress.

These three examples illustrate how the initial years of the Ursuline settlement in Toulouse were, episodically, blighted by conflict, and this despite the intensity of the Catholic Reformation effort in the city. They did find that their initial congregational form and the novelty of their unapproved structure constituted a considerable obstacle to their success with the city's elite classes whose support was so essential to their success. Therefore, Marguerite de Vigier soon decided to take drastic measures in order to secure the future of her life-long commitment to the Ursuline project. By 1609, the house had not yet been officially approved by the local Parlement, the monarch, or even the Pope. Therefore, wary of potentially fatal attacks against her congregation, Vigier decided to take a course of action that was to change the face of her Ursuline community beyond recognition.

By the year 1609, the Ursuline house counted twenty-seven congrégées and exhibited all the signs of a healthy community, the popularity of which increased steadily under the umbrella of protection provided by Cardinal-Archbishop Joyeuse and conseiller Bourret. ${ }^{53}$ Furthermore, the community's archive shows that between 1610 and 1616, it welcomed another nineteen members, while its school was, according to Parayre, becoming increasingly popular, both with boarders from wealthy backgrounds and with less privileged day pupils. ${ }^{54}$ However, despite such seemingly favourable auspices, Marguerite de Vigier felt that the foundations of her work were not as stable as she wished. Therefore, in order to strengthen the position of the Ursuline house in Toulouse, Antoine de Vigier (the foundress's brother, of the Congregation of the Christian Doctrine) was sent as a representative to Rome in 1609; his brief was to present Pope Paul V with the congregation's request to become an enclosed 
convent. ${ }^{55}$ In other words, these independent congrégées wished to relinquish their autonomy, submit to episcopal control, enter the state of religion and become nuns.

The community's records indicate that although conventual life seemed at odds with the catechizing and teaching brief of the Ursulines, it was not imposed upon the community by ecclesiastical authorities but rather came as the direct result of the women's request. Their decision to opt for enclosure of their own accord seems to indicate that Vigier's followers expected to gain something out of such a transformation. ${ }^{56}$ Why did the community wish to become a convent when its initial form as a lay congregation allowed it to enjoy a degree of independence and freedom of initiative that it would never have if it became a nunnery? Upon taking the habit, the Ursulines would become confined to their convent and claustration would be sure to threaten their freedom of manoeuvre. Since the establishment's aim was to teach and evangelize all ranks of the Toulousain female population, how could it propose to serve its active vocation by becoming enclosed?

The community's Memoirs of the beginning and progress of the Order of St Ursula give a narrative of the foundation of the Ursuline house in Toulouse. For the year 1609 , the chapter is eloquently entitled: 'How mother Vigier contacted Rome to ensure the vocation [of the community] by entering the religious Orders' ${ }^{57}$ This title implies that the community envisaged the appeal to Rome as a means to save itself from potential danger and to secure its future in the city. The chapter itself shows that Vigier feared that the budding congregation she had nurtured for five years, might become the victim of potential opposition and be destroyed. Seized by the force of this sentiment, she resolved to transform her congregation into a convent, so as to secure its future. The manuscript explained: 
[she] feared that, one day, one of the devil's tricks might lead this company to be dissolved. Therefore, in order to ensure its future, she and the aforementioned girls resolved to send a plea to Rome, asking for the Holy Father's intervention. They begged him to agree to the elevation of their house into a monastery of the Order of Saint Ursula. ${ }^{58}$

When Vigier perceived she had no alternative but to secure recognition and status by becoming religious or jeopardize the house's prospects, she opted for action. Thus, the decision was essentially palliative: had the Ursulines felt entirely safe in their informal congregation, they would probably not have felt the need to apply for transformation into a cloister. Finally, Parayre's explanation of this episode shows that the chronicler himself understood the transition from congregation to convent as a pragmatic move. He wrote: '[Vigier resolved] to elevate this congregation into religion, so as to secure it through this most effective of all means'. ${ }^{59}$ The evidence indicates that, in Toulouse at least, the congrégées' decision to become nuns was, at least initially, motivated by a desire to avoid potential suppression; moreover, in 1609, it was the first French Ursuline establishment to request elevation into a convent.

Whereas the initial Ursuline congregations of Provence and the ComtatVenaissin remained tightly linked to their Italian heritage, the Toulouse community operated in an influential ville parlementaire whose Catholic temperament revealed a pronounced Gallicanism. We have seen that, in 1604, the local Parlement had received Vigier and Blanchet with extreme caution and allowed them into the city on a provisional basis only, since their congregation had not as yet been approved by the king. ${ }^{60}$ In 1609, the congrégées' unofficial status still constituted their main weakness and their new model of the unenclosed religieuse presented the city of Toulouse with an unresolved ambiguity that made even its most devout Catholic families ill at ease. 
Marguerite de Vigier's plea for the elevation of her community into an enclosed convent was one of the most astute decisions she was to take while she was at the head of the community, and it found a specific resonance in local politics at Toulouse. It is likely that confrontations with influential local families had dented Vigier's confidence, making her more acutely aware that her congregation was institutionally in breach of the Decrees of the Council of Trent. ${ }^{61}$

Therefore, the Toulousain house resolved upon an apparently paradoxical, yet shrewd course of action: it would embrace conventualization in order to safeguard its active, educational vocation. In this respect, although there is no doubt that the Ursulines of Toulouse were profoundly respectful of traditional Catholic institutions and values, one could say the sisters were manipulative even in their open profession of subjection to patriarchal rules. Evidence indicates that the Toulousain congrégées purposely endorsed traditional female subjection to male authority in order to accomplish their self-appointed educational mission. In effect, they complied with the conservative decrees of Trent so as to be in a better position to transcend them. As L. Lierheimer explained in her study of the French Ursulines, 'enclosure provided the basis for a new ideal of community, an ideal that was in some ways more original than that of their uncloistered predecessors. ${ }^{, 62}$ Certainly, the history of the house on the Rue des Trois Rois Vieux indicates that, far from being a constricting and repressive decision imposed unilaterally by the ecclesiastical authorities upon unwilling women, enclosure represented an affirmative and constructive development.

However, the papal understanding of a female religious house differed widely from that of the Toulousain petitioners. In 1609, the pope refused the Ursulines the privilege of becoming a religious order in their existing form, since the Council of Trent, endorsing the decrees of Lateran IV, had prohibited the founding of new orders. ${ }^{63}$ Since Saint Ursula had not been a nun herself, she could not be the patron of 
an order, and Paul V asked the congrégées to submit to one of the pre-existing approved religious Rules. ${ }^{64}$ The congregation deliberated and opted for the Rule of Saint Augustine, which prescribed a moderate type of asceticism that they deemed particularly suited to their active way of life. ${ }^{65}$ In 1614, Antoine de Vigier was dispatched to Rome a second time, and finally came back to Toulouse, the bearer of a Papal Bull dated 9 April 1614, elevating the Toulouse congregation into a convent. ${ }^{66}$

Revealingly, the Bull obtained in April 1614 was entitled Bull of elevation of the Ursulines congrégées into religion of the Order of hermits of Saint Augustine. ${ }^{67}$ The very use of the lexicon of monasticism seemed to seal the alignment of these Ursulines to a norm of the enclosed life. The text specified:

[The sisters shall] live under the yoke of religion, perpetual enclosure, and regular observance, under the jurisdiction, visitation, and obedience of the present archbishop of Toulouse and his future successors. [They shall] take the vows of poverty, chastity and obedience, and nevertheless attend $[\ldots]$ to the instruction of the aforementioned girls, on condition that, while the pupils live in the monastery, they too keep the rules of enclosure. ${ }^{68}$

Despite its lengthy phraseology, this passage is remarkably clear: Paul V elevated the congrégées into nuns and thereby ordered them to keep their enclosure so closely as to teach boarders only, within the confines of the cloister. As a consequence, the Toulousain Ursulines would retain none of their initial particularities. Under such terms, the house's elevation into religion entailed its abandonment of all interaction with the local girls of the externat: it seemed that Vigier's plan had backfired and that her community's far-reaching educational mission had been unwittingly suppressed.

In 1614, although Marguerite de Vigier had succeeded in securing papal approbation, she had failed to obtain the validation she had initially envisaged, as a 
participant in the Catholic mission of education in the Toulouse area. The Bull did not show that the Pope had understood the congregation's wish to continue their teaching activities for day pupils, albeit within the safety of the cloister. His protection came at the cost of the house's freedom to catechize all who cared to listen at their grille and to teach externs in their classrooms.

This came as something of a shock for the Ursulines of Toulouse, who quickly decided that it was contrary to the essence of the congregation's vocation. The community's records make it very clear that, despite their plea for enclosure, the congrégées remained whole-heartedly dedicated to their initial evangelizing vocation: though they were to become nuns, they continued to view themselves essentially as teachers. The manuscript book entitled Memoirs of the beginning and progress of the Order of Saint Ursula gives the following account:

When the time came to implement the aforementioned Bull, there were six [congrégées] who, moved by their zeal for the Christian doctrine (and fearing that their entry into religion would bring them to abandon it, since our Holy Father did not mention teaching externs in his Bull) refused to become religious. ${ }^{69}$

Significantly, six out of the twenty-six sisters refused to take the habit unless the Bull specifically acknowledged their teaching duties towards externs. ${ }^{70}$ Indeed, most of the early members had felt deeply drawn to the community because of its innovative profile which, unlike that of traditional convents, involved interaction with other women and the instruction of the local youth.

Documents show that Jaquete de Maynie (1588-1631, in religion soeur SaintJean l'Evangéliste), deeply convinced that the community's main raison d'être was its educational vocation, became the leader of the six congrégées who, in 1614, protested against the papal Bull of enclosure, which they deemed incompatible the Ursulines' original vocation. ${ }^{71}$ She and her fellow protesters refused to take the habit unless the Bull acknowledged the community's teaching duties toward the externs; in fact, their 
movement was supported by the entire congregation, who delayed their entry into religion while Antoine de Vigier was again sent to plead anew with Pope Paul V. At long last, a further Brief was issued which dissipated all doubt concerning the Ursulines' right to teach day pupils. This Brief, dated 3 October 1616, bore a title that was as revealing as that of the preceding Bull: Papal Brief to join the institute of the Christian doctrine to monastic life. In it, Pope Paul V now agreed to the Ursulines' request to teach externs:

We order $[\ldots]$ the aforementioned nuns to instruct, free of charge, the aforementioned girls by teaching them, above all else, the piety and virtue that are worthy of Christian virgins, as well as a summary of Christian doctrine [...] However, these representatives of the world will be allowed to enter the convent only for as long as the Holy See will permit. ${ }^{72}$

Thus, by 1616, the Toulousain Ursulines had obtained a supplementary papal Brief unequivocally instructing them to teach not only their enclosed boarders but also local externs. These girls, often of lower social status, were expressly allowed to enter and leave the convent to receive their lessons on a daily basis. Such an outcome was a tactical tour de force, through which the congregation formally accepted the patriarchalist conception of religious women - enclosed and contemplative - in order to secure the safety of its active teaching initiative. Approved by the Pope, and properly enclosed, yet actually ordered by papal decree to teach and catechize externs, the Toulousain Ursulines had thus become virtually invulnerable to opposition. It was only at this point, seven years after their original appeal of 1609, that the congrégées of Toulouse were truly prepared to become nuns. With the exception of one anonymous sister who left, and another who died, ${ }^{73}$ all remaining twenty-four congrégées entered the religious life, took novices' habits together and later became professed in December 1616. They had five different classrooms, with five main teachers. ${ }^{74}$ In January 1617 , six lay sisters also took their solemn vows: thus, in its 
initial months as an enclosed convent, the Toulousain house counted thirty inmates. ${ }^{75}$ In the year 1617, another seven young women became professed Ursulines (six professes and one converse), and throughout its history, the convent generally housed between thirty-five and forty professed nuns at any one time. ${ }^{76}$

Thus, although the Toulouse house first petitioned for enclosure in 1609, it was transformed into a convent only in 1616. In the meantime, the passage from the state of simple lay congregation to that of approved religious establishment had already been realized by the Parisian community in the Faubourg Saint-Jacques, which petitioned for, and obtained papal approval, in $1612 .^{77}$ However, the issue of teaching externs was to be a thorn in the side of the Parisian community; although its members took a teaching vow, its papal Bull mentioned teaching in a non-specific way that did not explicitly refer to externs. Concerns were repeatedly raised by members of the community on the subject. ${ }^{78}$ Nevertheless, the decision to become enclosed was subsequently taken by most Ursuline houses across France during the 1620s and 1630s, and the Toulouse formula was significant in defining a working role for enclosed religious in the France of the Catholic Reformation.

\section{V}

Enclosure had been a quintessential condition for the elevation of the Toulousain congregation into a convent. Consequently, when Paul V's Bull of 1614 allowed the establishment to become a cloister of the Order of Saint Augustine, the sisters officially renounced any physical involvement in the world. According to the Constitutions of the Toulousain house, they could vacate the premises only when in actual danger of their lives. The Constitutions de l' Ordre des Ursulines de Toulouse specified the only legitimate reasons for leaving the convent as follows: 
if [the sisters] suffer from leprosy or contagious disease, or in case of fire, flooding or war, or else in order to be employed for the foundation or the restoration of some monastery, and this only with a written licence from Monseigneur the Archbishop or his Vicar. ${ }^{79}$

This extract is taken from the ninth chapter ('Of enclosure') of the book of Constitutions. It is significant that this is noticeably the most lengthy chapter out of a total of thirty three; it leads to another long descriptive chapter dedicated to the parloirs, thereby illustrating the strict surveillance imposed upon any communication with the outside. ${ }^{80}$ These parloirs consisted of a grilled reception foyer for occasional conversation with visiting relatives; they were fitted with a double row of spiked iron bars and they shut with tinplate in which small holes had been drilled. The only aperture consisted of a small window that was opened to speak to relatives, and these conversations were to be conducted only with the Mother Superior's authorization, and under the surveillance of a fellow sister. The partitions segregating the convent from the secular world seemed unforgivingly hermetic, and were generally to be found in all French Ursuline establishments. ${ }^{81}$

The enclosure was therefore a literal reality, embodied in the physical presence of high walls acting as a distinct separation between the 'outside' and the 'inside'. Neither the nuns nor the boarders had any insight into the life of the city: they lived in isolation from society. Yet, despite its solemn vow of cloture, the congregation in the Rue des Trois Rois Vieux remained faithful to its far-reaching educational vocation. Both the contemplative and the active life seemed to hold equal importance in the principles of the Toulousain establishment: 
[The Ursulines] must not be content with being simply religious, but [they are] also teachers of Christian doctrine $[\ldots]$ and the excellence of this vocation should be impressed upon them; those who will not be inclined or disposed towards this design will not be received in any way. ${ }^{82}$

The Ursulines had made a strategic choice in becoming enclosed, since the propriety of the cloister gave them a recognized and unambiguous civil status and an undisturbed life in good repute. Cloistered nuns were thus placed in conformity with gender expectations in respectable society, as well as in obedience with the decrees of Trent. However, the Ursulines of Toulouse did not consider themselves as traditional, contemplative religious women, as can be see in their Constitutions, which highlighted the fact that their vocations combined religious observance with the teaching of Catholic doctrine.

Nevertheless, the tension between monastic observance and teaching activities was felt acutely. If the sisters could not go out of their convent, was the scope of their teaching necessarily limited to the confines of the cloister? The Ursulines needed to find a practical compromise allowing them to teach girls without breaking their vow of perpetual enclosure: conventual life needed to be adapted in order to accommodate both aspects of their vocation. How could they house combine the respect of their new enclosure with their primary teaching vocation? Whilst guaranteeing a degree of security, did monastic life represent a restriction upon the sisters' pedagogical vocation?

Traditional conventual life was ingeniously reorganized according to a complicated structure, and a compromise was reached to suit the sisters' educational purpose. First, the nuns themselves were enclosed and bound by solemn vows. The convent was re-designed so as to accommodate them in their own quarter while, during their period of probation, the young novices occupied, another part of the building. ${ }^{83}$ Along with professed and prospective nuns, the Ursuline house in Toulouse also provided for students; their boarders were lay pupils, who lived in the convent and were submitted to enclosure in the same way as were the sisters. ${ }^{84}$ They lived in a separate wing of the building, and did not mix with either the nuns or the 
novices outside the classroom. The day pupils represented the last element in the structure: they were allowed in the convent's classrooms for their daily lessons, but returned home every evening. Compared with the nuns, the novices, or even with the boarders, these day pupils were seen as the agents of the world, the only inmates to have contact with the outside. ${ }^{85}$ The students gathered outside the cloister door, which was opened for them at seven o'clock. They entered the classroom by this exterior door, which was then immediately locked again behind them; when the door was secured, the teachers entered the classroom by an interior door, itself guarded on the inside by a soeur portière. The classrooms, therefore, could be compared to a sort of airlock between the inside and the outside, secured at either end by heavy, doublelocked doors. Thus, the Toulousain Ursulines designed a daily routine to enable the externs to enter the convent whilst allowing only minimal contact with the outside world.

In terms of structure, this represented the most innovative thread in the Ursuline fabric. The day pupils, who were allowed to enter the convent's classrooms, returned home every evening; these girls did not belong to the religious establishment, they did not partake either in its enclosed life or regular practice, and their daily entrance required some amendments to traditional conventual rule. Although the sisters did not actually breach their vow of enclosure, the teaching of externs implied that the convent opened its doors and allowed an exchange between the inside and the outside. This minor infringement of the rule of enclosure was enough to enable the Ursulines of Toulouse to influence and catechize hundreds of girls.

This, I believe, brought a new constituency within the ambit of the convent and allowed these girls to benefit, to a degree, from the spiritual charge conferred by enclosure. Without being elements of the cloister themselves, they were able to soak up its pious atmosphere, to experience its regular routine and to learn in its classrooms. I would therefore argue that, if the externs permitted part of the world to penetrate the convent, they also enabled some of the convent's essence to seep out into the world. The conventual bubble was not hermetically sealed any longer, and the day pupils were the main beneficiaries of this change. Thus, in the Rue des Trois 
Rois Vieux, enclosure had become active, thereby embodying the 'fluidity' that Linda Lierheimer described as 'a continuum from the convent to the world beyond' ${ }^{86}$ To use her lexicon, the Ursuline day classes functioned as a 'bridge', or a 'no-man's land' between the spheres of the public and the private, between the world outside and the conventual space inside of enclosure. ${ }^{87}$ When considering the evidence presented above, one can only agree with Lierheimer when she argued that the Ursuline sisters 'expanded the convent into the world'. ${ }^{88}$

Enclosure, although it had been adapted in order to allow the teaching of externs, nevertheless implied the end of all other kinds of apostolic works that required interaction with one's neighbours. ${ }^{89}$ However, the establishment in Toulouse managed to preserve some of the original Italian Ursuline spirit of apostolic works by organising a parallel lay association composed of married or widowed ladies who, though they did not want to become nuns, wished to be linked to the Ursuline congregation. These Dames de Sainte-Ursule carried out apostolic works in the city: they visited the sick, relieved the poor and helped prisoners. ${ }^{90}$ In this initiative, Marguerite de Vigier seems once more to have been a pioneer, since it was she who organised the first partnership between an Ursuline convent and its parallel lay company; this model was subsequently adopted throughout France by the communities of other cities such as Bordeaux, Dijon or Grenoble. ${ }^{91}$ Thus, the evangelical brief of the convent's initial 'mixed' life was preserved through its close links with the Compagnie des Dames de Sainte-Ursule; in Toulouse, this impulse remained strong, and the Compagnie counted between forty-five and sixty members at all times. $^{92}$ Although the congrégées of Toulouse, and across France at large, had been obliged to abandon their unenclosed and pioneering apostolate, they had nevertheless found a compromise that allowed them to remain an active female force within the Church. ${ }^{93}$

Thus, the Toulousain Ursulines were cautious never to break the rules, nor expose themselves to either clerical or secular criticism; however, they learned the art of gently bending traditional monastic regulations, in order to serve their original 
educational purpose. By 1616, they had concluded their dealings with Rome and finalized both the essence of their vocation and the status under which they operated. In the process, the congregation had undergone major structural changes, but it had successfully negotiated its niche within the Counter-Reformation movement.

* Dr Laurence Lux-Sterritt is a teaching assistant in the Departments of History and French at the University of Lancaster, Bailrigg, Lancaster, LA1 4YG (email: 1.lux@lancaster.ac.uk).

${ }^{1}$ See works such as H. Brémond, Histoire littéraire du sentiment religieux en France depuis la fin des guerres de religion jusqu'à nos jours, 11 vols. (1971); R. Briggs, Communities of belief: cultural and social tensions in early modern France (Oxford, 1989); P. Chaunu, L'église, culture et société: éssai sur réforme et contre-réforme (1984); G. Hanlon, Confession and community in seventeenth-century France: catholic and protestant coexistence in Aquitaine (Philadelphia, Penn., 1993); D. Potter (ed.) The French wars of religion: selected documents (1997); and M. Richard, La vie quotidienne des protestants sous l'ancien régime (1966). Also R. Taveneaux, Le catholicisme dans la France classique, 1610-1717, 2 vols (1980), i, 22-28.

${ }^{2}$ L. Châtellier, L'Europe des dévots (1987).

${ }^{3}$ E. Rapley, The dévotes. Women and church in seventeenth-century France. (Kinston, Ont, 1990), pp.193-6.

${ }^{4}$ J. Viguerie, Le Catholicisme des Français dans l'ancienne France (Paris, 1988), p. 166.

${ }^{5}$ On Catholicism and women in early modern Europe, see such works as: R. Bridenthal and C. Koonz (eds.) Becoming visible: women in European history (Boston, 1977); E. Clarck and H. Richardson (eds.) Women and religion. A femininst sourcebook of Christian thought (San Francisco, 1977); J. Delumeau (ed.), La 
religion de ma mère (1992); S. Marshall (ed.) Women in Reformation and CounterReformation Europe. Private and public worlds (Bloomington, Ind., 1989); M. Miller Migliorino, Sexuality and authority in the Catholic Church (1995); P. Ranft, Women and the religious life in premodern Europe (Basingstoke, 1996); Rapley, The dévotes; and M. Wiesner, Women and gender in early modern Europe (Cambridge, 1993). Also, E. Weaver's article 'Women and religion in early modern France: a bibliographical essay on the state of the question,' Catholic Historical Review 67 (1981), 50-59.

${ }^{6}$ For illustrations of this new active outlook, see M. Chalendard, La promotion de la femme à l'apostolat 1540-1650 (1950); Châtellier, L'Europe des dévots; $\mathrm{H}$.

O.Evennett, The spirit of the Counter-Reformation (Cambridge, 1968) and Rapley, The dévotes. See also articles such as M.C. Gueudré, 'La femme et la vie spirituelle', Dix-Septième Siècle 62 (1964), 47-77 and C. McCarthy, 'Igniatian charism in women's congregations', The Way, supplement 20 (1973), 10-18.

${ }^{7}$ P. Hoffman, Church and community in the diocese of Lyon, 1500-1789 (New Haven, Conn, 1984), p.115.

${ }^{8}$ See N. Zemon Davis, Society and culture in early modern France, eight essays (Stanford, Cal, 1979), particularly 'City women and religious change', pp.65-96 and 'Women on top', pp.124-151.

${ }^{9}$ It was in fact the Parlement of Toulouse, the second largest and most influential after Paris, that had formed the very first Holy League in France, on which the Parisian League was modelled in 1585: see P. Wolff (ed.) Histoire de Toulouse (Toulouse, 1974), p. 286.

${ }^{10}$ P. Wolff, in Toulouse, Histoire des diocèses de France (Paris, 1983), p. 98, argues that between 1558 and 1561, about 30 per cent of merchants were Protestant converts, while only 16 per cent remained steadfast Catholics. Similarly, 46 per cent of the bourgeois were Protestants, against 39 per cent of Catholics. For more detailed studies on Protestantism in Toulouse, see J. Davies, 'Persecution and protestantism: 
Toulouse, 1562-1575', Historical Journal 22 (1979), 31-51 and 'Notes sur les sources de l'histoire du protestantisme toulousain au seizième siècle', Bulletin de la société de l'histoire du protestantisme français 127 (1981), 103-6. Also M. Greengrass, 'The anatomy of a religious riot in Toulouse in May 1562', Journal of Ecclesiastical History, 34 (1983) 367-91 and 'The sainte union in the provinces: the case of Toulouse', Sixteenth Century Journal, 14 (1983), 469-96.

${ }^{11}$ A. Auguste, Etude sur la réforme catholique au XVIIe siècle dans l'ancien diocèse de Toulouse (1913); A. Salvan, Histoire générale de l'Eglise de Toulouse, 4 vols (Toulouse, 1861); R. Schneider, 'Urban sociability in the old regime: religion and culture in early modern Toulouse', unpublished $\mathrm{PhD}$ dissertation, University of Michigan, 1982 and Public life in Toulouse, 1463-1789: from municipal republic to cosmopolitan city (Ithaca, NY and London, 1989); Wolff (ed.), Histoire de Toulouse, and idem, Histoire du Languedoc (Toulouse, 1967).

${ }^{12}$ B. Bennassar, 'Des années de Ligue aux jours de Fronde (vers 1560- vers 1630)', in Wolff (ed.) Histoire de Toulouse, p. 280.

${ }^{13}$ François de Joyeuse (1562-1615) was the brother of the extremely influential Anne de Joyeuse, amiral de France. In the debate concerning the reception of Tridentine Decrees in France, he worked as protecteur de France à la cour de Rome, a position that testified to his family's engagement in the Catholic cause. When he arrived in Toulouse in 1588, he led the Catholic revival of the city. In 1606, he was made legate of the Pope, before presiding over the Etats-Généraux in 1614: see Michaud, Dictionnaire de biographie universelle (reprinted Graz, 1968), xxi, 276-7.

${ }^{14}$ Châtellier, L'Europe des dévots; Chaunu, L'Eglise, culture et société; Zemon Davis, Society and culture; Delumeau, La religion de ma mère; Rapley, The dévotes. ${ }^{15}$ See Viguerie, Le Catholicisme des Français, p. 166, and Schneider, Public Life in Toulouse, 1463-1789, pp. 208-10.

${ }^{16}$ Rapley, The Dévôtes, p. 48.

${ }^{17}$ M.C. Gueudré, Histoire de l'Ordre des Ursulines, 2 vols (1960), ii, 148. 
${ }^{18}$ The Italian origins of the movement have been explored in detail in T. Ledochowska, Angèle Merici et la compagnie de Sainte Ursule à la lumière des documents (Rome, 1967). See also P. Caraman, Saint Angela: the life of Angela Merici, foundress of the Ursulines 1474-1540 (1963); D. Latz, 'Sainte Angèle Merici et les courants spirituels de la renaissance italienne', Thèse de Doctorat, Université de Strasbourg 2, 1986; B. O’Reilly, St Angela Merici and the Ursulines (1880) and M. Reidy, The first Ursuline: the story of St Angela Merici (1962).

${ }^{19}$ The main work of reference concerning the early Ursulines of Provence and the Comtat-Venaissin is C. A. Sarre's Vivre sa soumission, l'exemple des Ursulines provençales et comtadines 1592-1792 (1997).

${ }^{20}$ His letter, dated 20 February 1604, is transcribed in A. Riboti, Examen d'un livre qui a pour titre la vie du P. Romillon avec plusieurs éclaircissements sur la première institution des congrégations de la Doctrine Chrétienne et des Ursulines en France (Toulouse, 1676), p.241.

${ }^{21}$ Riboti, Examen., p. 242, letter dated 8 March 1604.

${ }^{22}$ Archives départementales de la Haute-Garonne (ADHG), 221H- 4. Since the manuscript folios kept in this bundle have been damaged by fire, the Archives départementales have not numbered them, and the reader will require special authorization to consult these documents.

${ }^{23}$ Primary documents (1604-1790) consist of forty-three bundles of manuscripts kept in series $221 \mathrm{H}$ in the $\mathrm{ADHG}$, and three additional bundles in series $1 \mathrm{G}$. Moreover, the Bibliothèque municipale of Toulouse keeps Parayre's Chronique des religieuses augustines ursulines de la congrégation de Toulouse, 3 vols. (Toulouse, 1681) which, despite Parayre's tendency to eulogize, have proved reliable when counter-checked against the Ursuline manuscripts; indeed, large sections of the Chronique used documents that had initially been written by the congrégées themselves, many of which are kept in ADHG, 221H-37. Ursuline historian Gueudré believes this was standard practice across France where, she claimed, many Ursuline communities 
deposited their manuscripts into male hands for the purposes of publication. See Gueudré, Histoire de l'Ordre des Ursulines en France, i, p.8. The later years of the Ursuline convent of Toulouse have been the object of a recent study by S. Klassen, 'Greying in the cloister: the Ursuline life course in eighteenth-century France', Journal of Women's History, 12 (2001), 87-112.

${ }^{24}$ H. J. Schroeder, (ed.) Canons and Decrees of the Council of Trent (Rockford, Ill., 1978), p.220.

${ }^{25}$ ADHG, 221H-25, f. 3, Notarial act, registering Arnaud Bourret's gift of a house to the women of the congregation of Saint Ursula.

${ }^{26}$ Chronique, part 1, p.21.

${ }^{27}$ ADHG, 221H-28bis, 5, Constitutions.

${ }^{28}$ Ibid. fo. 3 .

${ }^{29}$ There are two undated manuscript books entitled Constitutions of the school and monastery of the convent of Saint Ursula of Toulouse in the Ursuline archive. After careful comparison, I am satisfied that they contain the same material, with only slight textual variations; however, I will refer to the text in $221 \mathrm{H}-28$ bis, item 5 , since this appears to be the older document. Only when passages have become illegible in $221 \mathrm{H}-28$ bis will I use text in $221 \mathrm{H}-41$

${ }^{30}$ For literature on the Jesuits, see W. V. Bangert, A history of the Society of Jesus (Saint Louis, Mo, 1986); J. Brodrick, Origins of the Jesuits (1949), The progress of the Jesuits (1946) and Saint Ignatius Loyola: the pilgrim years (1956); G. E. Ganss, Saint Ignatius' idea of a Jesuit university: a study in the history of catholic education (Milwaukee, Wis., 1956); F. Génin, Les jésuites et l'université (1844) and M. A. Lynn, The Jesuit mind: the mentality of an elite in early modern France, (Ithaca NY, 1988)

${ }^{31}$ The Ursulines' conception of instruction as a way to save souls was indeed very close to that of the Society of Jesus. Although the Ursulines of Toulouse did not 
overtly claim any privileged links with the city's Jesuits, their house on the Rue des Trois Rois Vieux was geographically situated near the Jesuit college and its novitiate. ${ }^{32}$ ADHG, 221H-41, Constitutions, fo. 27 and Sarre, Vivre sa soumission, p. 297. ${ }^{33}$ See, inter alia, Mère de Pommereu, Les chroniques de l'Ordre des Ursulines recueillies pour l'usage des religieuses du mesme Ordre (1676) and Règlemens des religieuses Ursulines de la congrégation de Paris, divisez en trois livres (1751). Also Gueudré, Histoire de l'Ordre des Ursulines, ii, pp. 134-5, P. Annaert, Les collèges au féminin: les Ursulines; enseignement et vie consacrée aux dix-septième et dixhuitième siècles (Namur, 1992), pp.44-47 and M. A. Le Bourgeois, 'Les Ursulines d'Anne de Xainctonge (1601). Contribution à l'histoire des communautés religieuses féminines sans clôture', Thèse de doctorat sciences théologiques, institut catholique de Paris, 1995.

${ }^{34}$ This was also clear in the community of Paris; see M. A. Jégou, Les Ursulines $d u$ faubourg saint-Jacques à Paris 1607-1662: origines d'un monastère apostolique (1981), pp.55-6.

${ }^{35}$ Chronique, part 2, pp. 338-75.

${ }^{36}$ ADHG, 221H-37, Memoirs. She worked efficiently in the town of Brive-laGaillarde, before moving on to Limoges, where her school proved very popular. ${ }^{37}$ ADHG, 221H-15, Professions de foi, fo. 225, 221H-29, register of professions, fo. 165 and Chronique, part 2, pp. 26-44.

${ }^{38}$ Details on Jaquete de Maynie can be found in ADHG, 221H-15, Professions de foi, fo. $214,221 \mathrm{H}-29$, register of professions, fo. 24; 221H-37, Memoirs; $1 \mathrm{G} \mathrm{663,} \mathrm{fo.} 23$ and Chronique, part 2, pp. 45-87.

${ }^{39}$ Chronique, part 2, p. 46.

${ }^{40}$ ADHG, 221H-37, Memoirs of the beginning and of the progress of the Order of Saint Ursula, ff. 1-2. 
${ }^{41}$ ADHG, 221H-25, fo. 9, Letter sent by the Vicar General [...] to call sister Marguerite de Vigier to found the congregation of Saint Ursula in the city of Toulouse.

${ }^{42}$ Gueudré, Histoire de l'Ordre des Ursulines en France, i, p. 132.

${ }^{43}$ The Ursuline documents indicate that, particularly in the early years, the congregation's relationship with Parlement was not always smooth. However, Parlement's papers, in ADHG series B, do not yield any information on the subject. ${ }^{44}$ ADHG, 221H-4, Royal letters of approval.

${ }^{45}$ Ibid.

${ }^{46}$ ADHG, 221H-37, Memoirs, fo. 2: in October 1604, on their way to Toulouse, the four missionaries were arrested and imprisoned in Pezenas. Their arrest bears witness to early modern fears of vagrants: the women, travelling freely in the company of men, were immediately suspected of being prostitutes and thieves.

${ }^{47}$ L. Lierheimer, 'Redefining convent space: ideals of female community among seventeenth-century Ursuline nuns', Proceedings of the Annual Meeting of the Western Society for French History 24 (1997), 213.

${ }^{48}$ Details on Despanez are found in ADHG, 221H-15, Professions de foi, fo. 212, $221 \mathrm{H}-29$, register of professions, fo. $25 ; 221 \mathrm{H}-37$, Memoirs, and $1 \mathrm{G} 663$, fo. 23 . See also Chronique, part 2, pp. 240-64.

${ }^{49}$ Chronique, pp. 338-75.

${ }^{50}$ Françoise Rabonite's story is documented in ADHG, 221H-15, Professions de foi, fo. 226; 221H-29, register of profession, fo. 11 and 221H-37, Memoirs.

${ }^{51}$ Chronique, pp.87-116.

${ }^{52}$ ADHG, 221H-37, Memoirs.

${ }^{53}$ ADHG, 221H-15, Professions de foi and 221H-37, Memoirs.

${ }^{54}$ Unfortunately, numbers of boarders and externs for that period are not available. The earliest register of boarders for the establishment on the Rue des Trois Rois 
Vieux starts in November 1771, when the school counted forty-seven boarders. ADHG, 221H-40.

${ }^{55}$ ADHG, 221H-37, Memoirs and Chronique, part 1, p.123.

${ }^{56}$ Annaert, in Les collèges au féminin, p. 46, stated that the Ursulines Toulouse, when they applied for enclosure, followed the example given by their consoeurs of Paris. The documents kept in the Toulousain archives disprove this claim and show that, though the Parisian establishment became a convent in 1612, the house in Toulouse had actually been petitioning to Rome as early as 1609 . Had it not been delayed in its dealings with the Curia, the house on the Rue des Trois Rois Vieux would have been the first French Ursuline congregation to be elevated into a convent.

${ }^{57}$ ADHG, 221H-37.

58 Ibid.

${ }^{59}$ Chronique, part 1, p. 129.

${ }^{60}$ ADHG, 221H-37, Memoirs, fo.29.

${ }^{61}$ See U. Strasser “ “Aut maritus, aut murus?” Women's lives in counter-reformation Munich 1579-1651', unpublished PhD dissertation, University of Minnesota, 1997, pp. 5-7 and L. Lierheimer, 'Female eloquence and maternal ministry: the apostolate of Ursuline nuns in seventeenth-century France', unpublished PhD Dissertation, Princeton University, 1994, p. 27.

${ }^{62}$ Lierheimer, 'Redefining convent space', 211.

${ }^{63}$ N. Tanner (ed.) Decrees of the ecumenical councils, 2 vols (London, 1990), i, 227 73.

${ }^{64}$ ADHG, 221H-37, Memoirs, chapter 9.

${ }^{65}$ In her Histoire de l'Ordre des Ursulines en France, i,113, Gueudré explained that all French houses of Ursulines subsequently adopted the Rule of Saint Augustine, which they deemed perfectly suited both to their gender and to their specific religious calling. 
${ }^{66}$ ADHG, 221H-37, Memoirs, and Chronique, part 1, pp.130-34. See also Gueudré, Histoire de l'Ordre des Ursulines en France, i, 252-3 and Sarre, Vivre sa soumission, pp. 55 and $83-4$.

${ }^{67}$ The Bull was originally written in Latin, and the ADHG hold both the Latin version and its translation into French in bundle $221 \mathrm{H}-4$. Another copy of the Bull is kept in 221H-25, fo. 25 .

${ }^{68}$ ADGH, 221H-4, emphasis mine.

${ }^{69}$ ADHG, 221H-37, Memoirs.

${ }^{70}$ ADHG, 221H-37, Memoirs ff.44-47 and Chronique, part 1, p.109. Brigite Seysol, widow of nobleman Pierre Delpech, who had joined Marguerite de Vigier in 1606 when she was already 80 years old, had died of old age in 1614. Thus, there remained only twenty-six congrégées.

${ }^{71}$ Chronique, part 2, pp. 45-87.

${ }^{72}$ ADHG, 221H-25, fo. 26.

${ }^{73}$ Madame de Causan, widow, ADHG, 221H-37.

${ }^{74}$ Chronique, part 1, p. 142.

75 These numbers have been collated from ADHG, 221H-15, 221H-29, 221H-37 and Parayre's Chronique.

${ }^{76}$ ADHG, 221H-15 Professions de foi and 221H-29, register of professions. See also Klassen, 'Greying in the cloister', 93.

${ }^{77}$ H. Leymont, Madame de Sainte Beuve et les Ursulines de Paris, 1562-1630 (Lyon, 1890) and M. A. Jégou, Les Ursulines du faubourg Saint-Jacques à Paris 1607-1662. Origines d'un monastère apostolique (1981).

${ }^{78}$ See Gueudré, Histoire de l'Ordre des Ursulines, i, 104-6.

${ }^{79}$ ADHG, 221H-28bis, 5, fo. 20.

${ }^{80}$ Ibid. fo. 20 passim and $221 \mathrm{H}-41$, ff 62-64. 
${ }^{81}$ The system was the same in Bordeaux and Paris, for instance; see Gueudré, Histoire de l'Ordre des Ursulines en France, ii, 242 and Règlemens des religieuses Ursulines.

${ }^{82}$ ADHG, 221H-28 bis, 5, Constitutions, fo. 44.

${ }^{83}$ Ibid. fo. 51.

${ }^{84}$ Ibid. fo.4.

${ }^{85}$ Ibid. fo. 12 .

${ }^{86}$ Lierheimer, 'Redefining convent space', 218.

${ }^{87}$ Ibid. 217.

${ }^{88}$ Ibid. 212.

${ }^{89}$ Rapley, The dévotes, p. 57. In fact, the community in Narbonne petitioned against this shift, claiming that the Ursulines' educational vocation could not possibly be entirely fulfilled in a cloistered house. It was nevertheless transformed into an enclosed convent in 1658, hence closing the chapter on the congrégées in France. ${ }^{90} \mathrm{ADHG}, 221 \mathrm{H}-28$ bis, item 2; this is a slim manuscript book containing the rules of the Compagnie des Dames de Sainte-Ursule. See also Chronique, part 1, pp.128-9. ${ }^{91}$ Gueudré, Histoire de l'Ordre des Ursulines en France, i, 165.

${ }^{92}$ ADHG, 221H-34, Rules of the compagnie des Dames de Sainte-Ursule. This manuscript book contains, at the back, a roll of entries in the company and a list of members at various dates.

${ }^{93}$ See Lierheimer, 'Female eloquence and maternal ministry', p. 17. 